\title{
Conflicting Spaces: Gender, Race, and Communal Spheres in Nadine Gordimer's Fiction
}

\section{Michelle Goins-Reed}

\section{OpenEdition}

1 Journals

Electronic version

URL: https://journals.openedition.org/ces/426

DOI: $10.4000 /$ ces.426

ISSN: 2534-6695

Publisher

SEPC (Société d'études des pays du Commonwealth)

\section{Printed version}

Date of publication: 10 June 2019

Number of pages: $51-60$

ISSN: 2270-0633

\section{Electronic reference}

Michelle Goins-Reed, "Conflicting Spaces: Gender, Race, and Communal Spheres in Nadine Gordimer's Fiction", Commonwealth Essays and Studies [Online], 41.2 I 2019, Online since 05 November 2019, connection on 16 July 2021. URL: http://journals.openedition.org/ces/426 ; DOI: https://doi.org/ $10.4000 /$ ces. 426

\section{(c) (i) $\odot$}

Commonwealth Essays and Studies is licensed under a Licence Creative Commons Attribution - Pas d'Utilisation Commerciale - Pas de Modification 4.0 International. 


\section{Conflicting Spaces: Gender, Race, and Communal Spheres in Nadine Gordimer's Fiction}

Nadine Gordimer's fictional characters embody unease and often resentment with social class, expected cultural roles, and place. In her fiction, the conflicting notions of space and self are tied to gender, class, and identity. Gordimer's characters are victims of circumstance, of birth, of place, but in addition to the feeling of exile linked to these factors, her fiction draws attention to female spheres, communal spaces, domesticity, and sexuality. This paper will examine the role of female spheres and spatiality through a feminist literary perspective. Though Gordimer's relationship to feminism was at best tentative, her work offers much to the field of feminist studies.

Nadine Gordimer's fiction has long reflected images of her home country of South Africa. Throughout decades of writing, Gordimer depicted her own culture and the societal changes that occurred during and after apartheid. Her fiction focuses on exile, in terms of class, gender, and identity. Likewise, Gordimer's characters find themselves struggling with societal expectations as well as their own identity. Her characters illustrate the changes in South African society, but they are also figures that must navigate a patriarchal system in which they have limited authority. Gordimer exposes the tension of gender roles and social class and explores the arbitrary nature of the patriarchal systems that aim to define her characters. Within their society, her characters attempt to occupy and reclaim spaces in which to define themselves. Gordimer's collection of short stories, Soldier's Embrace, written during apartheid, and her post-apartheid novel, The Pickup, along with the lesser-known story "The Second Sense," highlight the possibilities that exist within gendered spaces, but also how these spaces are limited when one crosses the color bar. These works, though a small selection of Gordimer's vast output, illustrate a range of female spaces during apartheid (and the Immorality Act) and after apartheid during different periods of Gordimer's creativity. Over the course of her career as a writer, Gordimer expanded the role of her characters to shed light on racial and gender inequality but additionally to encompass the potential of bonds within gendered and communal spaces and beyond South Africa. The town and country, kraal and hut, the bedroom and kitchen, the sewing room, the city and the desert are all spaces upon which Gordimer's evolving ideas on gender and race play out.

Given the timespan of Gordimer's literary output, it is not surprising that criticism of her work has evolved. Gordimer's fictional and personal attempts to tackle social issues prevalent during apartheid and post-apartheid South Africa especially concerning race and gender have been well documented. Her fiction suggests that one rethink relationships among whites and blacks and men and women. However, Gordimer's relationship with feminism itself has been ambivalent and at times dismissive. In early interviews, critics note Gordimer's reluctance "to think of herself as a feminist writer" (Driver 33) and her "expressed impatience with the feminist movement" (Head 19). Robin Visel acknowledges that although Gordimer "said several times that the women's liberation movement is irrelevant in South Africa," her fiction shows that this statement is an oversimplification (34). While Gordimer did not see herself as anything other than 
a writer who happens to be a woman, she "gives particular polemical force to her documentation of inequality in male-female relationships by employing it to define female growth" (Driver 34). Additionally, Gordimer's oeuvre offers much in terms of how women's identities are formed within the confines of a restrictive culture. As Karen Lazar points out in her 1994 study of Something Out There, Gordimer's fiction "shows the potential for transgression, for alternative ways of seeing, amidst the existence of patriarchal-cum-racist stereotypes" (58).

Regardless of Gordimer's personal feelings and public remarks regarding feminism and her own refusal to be identified as a feminist writer, her writing offers a significant contribution to the field of feminist studies. Chanty Mohanty writes that feminist "analysis has always recognized the centrality of rewriting and remembering history, a process that is significant not merely as a corrective to the gaps, erasures, and misunderstanding of hegemonic masculinist history but because the very practice of remembering and rewriting leads to the formation of politicized consciousness and self-identity" (78). Gordimer's fiction contributes to the history of South Africa and of the political environment that prevails outside and within her fictional worlds. However, there are limitations to her female characters' ability to emancipate themselves from the political and social systems governing the world in which they live. White immigrant or white South African women are often illustrated as negotiating patriarchal systems and circumventing consequences from non-conformity in order to secure their social position or to free themselves of their privileged obligations. Although white women in Gordimer's fiction have freedom to move outside their social circle, they are not always portrayed positively. Mary West argues, "much of Gordimer's fiction has offered a severely critical reading of white women's complicity and/or ineffectuality in facing South African racial realities" and their "insulated and selfish white womanhood" (79). Black and Muslim characters are at times eroticized or are generic backdrops for a South African or unnamed setting. Within the gendered spaces occupied by blacks and, in her later fiction, by Muslim women, the cultural norms that dictate behavior are tied to traditional roles and communal expectations. Additionally, their spaces are disrupted and dictated through laws imposed on them during and after apartheid.

Soldier's Embrace (1980) and more particularly the story "Town and Country Lovers" depicts sexual relationships across the color bar and provides an early example of Gordimer's fictional confrontation with apartheid and the Immorality Act. Originally published in The New Yorker in 1975, the story portrays successful white men who become intimately involved with black girls. Although "Gordimer never portrays a cross-racial relationship that can sustain the pressures of apartheid" (Knox 77), the stories offer an interesting perspective on sexuality and race as well as communal and private spaces. In "One," a non-native white geologist living in the city begins a sexual relationship with a local black girl who works in a shop as a cashier. In "Two," Thebedi, a local black girl and worker on a farm, becomes the object of desire for Paulus Eysendyck, the son of the white farm owner. Town and country are pivotal spaces of transgression in the story. Although people are living in the spaces relegated to their race, whites in the nicer city flats and farmhouses, blacks in the kraal and the outskirts, the story emphasizes the consequences of interracial relationships and penetration into spaces allocated to whites. In both settings the relationships begin privately and away from the eyes of 
the other's social circle, but each coupling ends when community people report their suspicions of a crime to law officials. Dr. Franz-Josef von Leinsdorf and the unnamed cashier are accused of having "carnal intercourse" (Gordimer, Soldier's Embrace 84) while Paulus is accused of murdering his child conceived with Thebedi. However, both cases are dismissed due to insufficient proof, and as the story implies, because the men are white and have high social status.

"Town and Country Lovers" opens with a description of Dr. von Leinsdorf who had been working in South Africa for almost seven years. According to the narrator, he has "no interest in the politics of the countries he works in" (Soldier's Embrace 74) and is only preoccupied with his work as a geologist. Originally from Austria, he resides in the Atlantis, a building with flats occupied by other whites. The unnamed young black girl with whom he begins a sexual relationship lives in the "West of the city [...] for people her tint" (76). Von Leinsdorf first encounters the girl at the local shop where she works as a cashier and begins a relationship with her when the girl takes on domestic duties inside his flat. One night, while she is quietly looking down and sewing a button on a pair of his trousers, he calls her a "good girl" and "touched her" (78). The girl is submissive and stays in his flat when he must attend social obligations. She makes "him welcome without a word" (80) into her body at night when he comes home. During some of her visits to von Leinsdorf's flat, he teaches her basic typing and corrects her English grammar. He occasionally takes her on excursions outside town where they cannot be observed. While they play at creating a domestic space, it is clear that the relationship will not last. The girl also knows that she cannot ignore the consequences of being found out. She lies to her mother about the nature of her relationship with von Leinsdorf and even his occupation, and she never stays the night. The relationship eventually draws the attention of others, and both are arrested. Leinsdorf pays a lawyer to assist both of them, and the charges are dropped.

In the country setting of "Two," Paulus and Thebedi, who had known each other as children and now are teens, consummate their relationship at a riverbed, where the two meet coincidentally during the summer. Paulus' yearning for Thebedi surpasses that for his white female school mates who "had never made him feel what he felt now, when the girl came up to the bank and sat beside him, the drops of water beading off her dark legs the only points of light in the earth-smelling, deep shade" (88). The intimacy described is one of mutual surprise, yet "they were not afraid of one another; they had known one another always" (88). The conversations between them that were once about his life and school experiences cease after the relationship becomes sexual. Instead, Paulus "told her, each time, when they would meet again" (88). The two continue to meet secretly at the river-bed and sometimes at the farmhouse when no one is home. Thebedi, like the unnamed cashier, makes sure that she is within her allocated space before allowing herself to be noticed: "each returned home with the dark - she to her mother's hut, he to the farmhouse" (88). Once Paulus turns nineteen and leaves for veterinary college and Thebedi marries another farm worker, the story shifts in tone.

As a white male and the son of the farmer, Paulus is expected to attend school and college with others like him and to be with other whites. Thebedi as well must adhere to the culture of her people and of that of a female. Her future husband, Njabulo, "asked her father for her" (89) and once money was settled they married. Thebedi gives birth two months later to a child that "was very light" and had "a quantity of straight, fine 
floss, like that which carries the seeds of certain weeds in the veld" (90). Her husband made no complaint about the early arrival of the baby as "there was no disgrace in that, among her people it is customary for a young man to make sure [...] the chosen girl is not barren" (90). When Paulus learns of the child, he enters the kraal to see the baby. His appearance in the kraal, a space he had not been in since he was a small boy, immediately causes concern. As he approaches, the "women turned away, each not wanting to be the one approached to point out where Thebedi lived" (90). He returns two days later, but goes into the hut alone to see the child, and the baby subsequently dies. After the child is buried, it is exhumed, because "someone - one of the other labourers? Their women? - had reported that the baby was almost white, that strong and healthy, it had died suddenly after a visit by the farmer's son" (92).

The charges against Paulus and Thebedi, like those in the first setting, are dropped due to insufficient evidence. Clearly the race of the men and their social status comes into play in the dismissal of charges. Although Dr. von Leinsdorf is Austrian, he is expected to adhere to the social rules like any other South African, but as a grandson of a baroness and successful geologist, he is easily able to afford legal counsel. Paulus as well has the financial and social backing of his own prominent family. As for the unnamed cashier and Thebedi, they are only able to escape conviction due to the ability of their partners to have the charges dropped. When they leave the communal space of their mothers and others of their own race, the girls become subject to the whims of their white partners and the laws of apartheid. Thebedi "wandered far from the kraal and her companions" (87) when she encounters Paulus. The unnamed cashier, out of sight of her mother and in the city, is easy prey for von Leinsdorf. He lures her with the illusion of domestic bliss in his private apartment. Gordimer shows in this early work that spaces are delineated by race and that when one leaves one's own space to occupy the others' space there can be no enduring relationship or positive outcome.

In her development of characters later in her career, Gordimer takes on post-apartheid issues and looks beyond spaces in farm velds to urban and desert environments outside of South Africa. While the author J.M. Coetzee felt that "the white writer in South Africa is in an impossible position" (qtd. in Spivak 195), Isidore Diala suggests that Gordimer, like Coetzee and Brink, "enhance[s] our understanding of the underlying implications of South Africa's peculiar history" (52). However, some hesitate to limit Gordimer to the position of post-colonial writer. Ileana Dimitriu believes that Gordimer "avoids what might be a temptation for the writer who turns from the peripheries of the ex-colony or post-colony" (160). Instead, Gordimer "presents the reader with the impact of liminality and exile on one's sense of identity and belonging, on one's relationships" (Dimitriu 167). Her fiction uses personal relationships to illuminate racial and social imbalance as well as how these elements shape gender roles. Later examples of her work show that the post-colony spaces wherein her characters choose to reside are affected by racial and gender inequalities. The remnants of the past linger in post-apartheid Africa and add to the alienation felt by her characters as they try to find their identity and form relationships outside their own country.

The Pickup and "The Second Sense" highlight Gordimer's approach to post-colony spaces. The texts focus on identity and exile within gendered and communal spaces as well as their effects on personal relationships. The central female characters in these two texts experience a sense of freedom through domesticity and immersing them- 
selves into the gendered spaces established for women in another country. As shown in these two texts, white women have the ability to use social class to their advantage and to negotiate their role in their society. Although both Julie and Zsuzsana become emigrants, Julie flees her privileged life in South Africa to join her Muslim lover and later her legal husband in an unnamed desert, while Zsuzsana and her husband emigrate to South Africa to escape an unstable political environment. While these characters at first exhibit marital happiness, the narratives end with each woman choosing for herself how she wishes to continue her life without her spouse. Both Julie and Zsuzsana undergo a transformation that solidifies their place in their new environments. The change they undergo is a result of their ability to become a part of female homosocial spheres and to use those spheres to navigate their positions in their new social systems. However, these two characters are dissimilar in the way they immerse themselves and how Gordimer presents their quest to find themselves. Julie, while referred to as "spoiled," due to her wealth, her independence, and even her feminism, bonds with the Muslim women of her husband's family and refuses to emigrate with him to the United States. Zsuzsana becomes the epitome of success by imitating the language and style of her South African female clients and ultimately initiates a divorce to be with a man who has more social status than her husband.

In the 2001 novel, The Pickup, Gordimer presents characters who are exiles, either within their own country or in another country and "widens her scope to reveal otherness among exponents of the East and West" (Cloete 52). While addressing the two protagonists' desire to flee their respective lives, the narrative calls into question gender roles and social class. Julie Summers and Abdu/Ibrahim ibn Musa see in the "Other" a freedom that cannot be obtained at home. Like other Gordimer stories written during post-apartheid, the novel "offers a picture of the new South Africa and its usual problems of race, class and bureaucracy, taken from a local to a global level," but what is different is the shift "from post-Apartheid Johannesburg to an Arab country and its villages, deserts and Muslim people" (Caraivan 6). Julie and Abdu serve as contrasts to show privilege and poverty and to examine the realms of what is legal and illegal. However, gender and the spaces in which gender comes into play are shown to have the greatest potential in the novel. Traditional female gender roles within homosocial bonds become powerful, whereas male gender roles are ineffectual and have no real authority within the context of female spheres.

As the novel opens, the scene presented takes place against the backdrop of modern South African life. Julie's car has broken down in a busy street when she is on her way to meet her friends at the EL-AY Café, a hangout for Julie and her "elective siblings who have distanced themselves from the ways of the past, their families" (Gordimer, The Pickup 23). They assist her in locating a garage. It is at the garage that Julie finds Abdu, an illegal immigrant from an unnamed country, "one of those partitioned by colonial powers on their departure [...] one of those countries where you can't tell religion apart from politics" (11). A few weeks after first meeting him, she brings him into her social circle. In time, Julie and Abdu begin a sexual relationship, and he eventually stops being a "grease-monkey" (92). He moves into her place, and the relationship becomes the focus of her friends' commentary: "There was talk: That relationship's getting heavy, our girl's really gone on that oriental prince of hers. Where was it she picked him up, again?" (36). This reference to Abdu as an oriental prince and as Julie's pickup reinforces his 
otherness. It also causes concern for Julie as it marks her transition away from her South African friends and the spaces that she has created for herself.

Abdu receives a letter from the Department of Home Affairs informing him "he must depart within 14 days or face charges and deportation to his country of origin" (52). With this letter, the narrative begins to transition to the second setting. Julie, although refusing to seek her father's assistance, finds a lawyer friend of her father's. After meeting with the lawyer and realizing there were no options, Julie wants to find someone else. Abdu stops her, and in this scene tries to assert his masculinity; "That was the message of that grasp on her forearm: I am a man. I am the one who is not for you but who possesses you every night: listen to me" (82). This gesture along with others later in the narrative points to Abdu's mistaken belief that Julie needs him physically and that his phallus holds power over her. Nigel Summers, her father, also fails to assert any real power over her. He regards her relationship and her decision to follow Abdu to his homeland as part of her being "spoiled." Both men fail at bending Julie to their will. Julie's "oriental prince" becomes a point of contention with her father, who in anger and resignation, chastises her and "in his shock and desire to sting his 'spoilt' child, lashes out at her by using her feminism against her" (Mount 113). He tells Julie: "as for women: you, you to whom independence, freedom, mean so much, eh, there women are treated like slaves [...] you are out of your mind" (Gordimer, The Pickup 97). Abdu as well regards Julie's decision to go with him as "stupidity" (94) and "struggles to come to grips with Julie's decision to abandon her friends, family and privileged life" (Montle and Mogoboya 64).

Once the setting changes to that of the desert where Abdu, in reality Ibrahim ibn Musa, is from, the dynamics of gender, especially within female spheres, are explored more fully. For Julie, it is with the women in this strict Muslim culture that she finds freedom from her family and privilege. While Gordimer intersperses the first part of the narrative with images of black and white South African women, they mainly serve as stereotypes to contrast with Julie and to illustrate her inability to accept the privilege of her social class. Nevertheless, it is her status as a wealthy South African woman that has given her the freedom, albeit in a Muslim culture, to actively reject her own culture. Interestingly, Julie cannot form significant female bonds in her home country; Gordimer "does not include any strong female characters in the first half of the novel" (Hunt 112). Julie's stepmother, Danielle, is portrayed as a perfect accessory to her father's success; "she was beautiful; trust her father for that" (Gordimer, The Pickup 41). Her mother living in California with Julie's casino-owning stepfather has little connection to her. Other South African women are merely backdrops in the street, patients at her uncle's gynecology office, or prostitutes in the EL-AY Café. This exclusion, intended or not, is telling.

As Julie disconnects from her South African life, she finds that in her new setting she ultimately seeks the solace of women for comfort. Emma Hunt argues that "the spaces to which Julie is drawn are gendered spaces - those of the family and the desert" (111). However, when she first arrives in the unnamed desert, she is out of place, and has no set role in the traditional Muslim world in which she has chosen to live. She is not one of them. When she asks, "Where's the bathroom?" (121), Ibrahim gets angry, he wants to "tell her once and for all what her ignorant obstinacy of coming with him to this place means, when she failed, with all her privilege at getting him accepted into 
hers" (121). Julie wants to explore her new environment, but is naïve about the cultural norms. Ibrahim sees this as her privileged ignorance and her need for an adventure:

Of course. Of course. Independent. This is the way she's accustomed to living, pleasing herself. Again. But that's impossible, here. He has to be with her, some member of the family, if there could be one who could be understood, has to accompany her everywhere beyond a few neighbourhood streets, that's how it is in the place he thought he had left behind him. It's not usual for women to sit down to eat with the men, today was a special exception for the occasion - does she understand. It's enough, for these people, that she goes about with an uncovered head - that they can tolerate with a white face, maybe. (122)

While Ibrahim cannot accept being back home, Julie wants to connect with her new family and their language; however, she is initially "not invited or even permitted to participate in the women's activities" (Mount 116). Her inability to penetrate the "women's sphere illustrates the intersectionality of gender, race, nationality, and geography; Julie is kept on the boundary until the other women learn more about how she will negotiate these differences" (Mount 116). When Julie wants to help the other women with cleaning dishes, "the women crowded about to prevent her from so much as putting her hands in water" (Gordimer, The Pickup 136). Ibrahim's mother is the central power in the female sphere; she decides if and when Julie will become part of their sisterhood. Without her say, Julie cannot be admitted into the women's space or allowed to become an integral part of the family. Ibrahim himself does not want Julie to fully integrate with his family. He shouts at his sister Maryam when she "kit[s]" Julie in traditional attire "like any village woman in the street" (162) and tells her to "take that thing off her" (162). This scene ends, not with Julie going to Ibrahim to calm him, but with his sister, "the two with arms again about each other on the sofa quietly as if Ibrahim's wife were a sister" (162).

In time, Julie forms simple connections with the women and children outside of Ibrahim's family. She teaches English to local children and local women, and then Ibrahim's sister and his sister-in-law join to exchange language. According to Derek Barker, "[Julie's] ability to communicate with members of the community is rudimentary - the only clearly positive relationship she has is with Maryam - no men interact with her and all other women keep her at arm's length - her possible place in the society is potentially self-affirming" (104). Although Julie is kept at arm's length, she is able to exist on the periphery and use her connection to Maryam to skirt the edges of the female domain. Andrea Spain argues that Julie "finds herself a part of a homosociality of women. It is an everyday life of common spaces, decisions, labor, and duty, rather than the privatized present and lifestyle scripted by her family" (767). Indeed, Julie does find herself part of the female spheres of her new family; however, it is still limited. The matriarch of the family expects Julie to participate fully in the culture to truly become one of them. To become accepted the expectation is that she should give birth. However, the mother does not speak to Julie directly of this; instead, Maryam tells her "they wonder why you do not get a baby. Then perhaps you will first marry here, our way" (166).

To additionally highlight Julie's struggle to find her place in this new world, Gordimer uses a recurring image of the desert, which becomes the site in which Julie can abandon herself and where she can reflect. It is in the desert that Julie has seemingly found the place where humanity ends and the unknown begins: "The desert is always; it doesn't die it doesn't change, it exists. But a human being, she, she, cannot simply exist; 
she is a hurricane, every thought bending and crossing its coherence inside her, nothing will let her be, not for a moment. Every emotion, every thought, is invaded by another" (229). The desert offers a stability that Julie has not found in her prior existence. The allure of the desert and its "eternity" is sublime; "there is no last time, for the desert. The desert is always" (246). When debating her life and her new world, Julie could "tell it to the desert; that is safe" (245). The endless desert is where Julie can be truly free; but more importantly, the desert "is outside of any social space" (Dimitriu 171). It has "no onlooker[s]" (Gordimer, The Pickup 171), and it comes to represent a space without limits, without clear boundaries, and without time.

At the end of the narrative, Julie decides to stay behind in the desert and to remain in a restrictive culture. She finds solace in its isolation and other female characters, while Ibrahim "began to feel that his manhood was in question," because she would not go to America with him (175). Ibrahim's mother now sees Julie as a conduit to draw her son back to her. Ibrahim realizes this when "she, who always has advice and a solution $[\ldots]$ has none for him. [...] Ah, an ally, that's it; but not his. An ally of the foreigner, she will be the one to restore the son to the mother" (258). Without his mother's support, Ibrahim understands that he has no authority over Julie. As a final gesture of his anger, Ibrahim "kept away from her [...] let her have an idea of what she doesn't realize [...] that she will be in this house $[\ldots]$ without the love-making she needs so much $[\ldots]$ without his love for her" (265). He again calls upon his sexuality and his belief that Julie will need him physically. Once he leaves in the cab, Julie goes to their room and the troublesome sister-in-law, Khadija, who "has never come to the lean-to [...], put an arm around her conspiratorially" and in Arabic, which "the foreigner understands enough, now," she tells Julie: "He'll come back" (267). This final gesture and her mother-in-law's realization that Julie has made a significant contribution to their lives solidifies Julie's place in the female sphere.

Gordimer leaves much to be questioned in terms of Julie's future and of her portrayal of South African women in general. Julie, of course, still has connections and money in South Africa if she chooses to utilize them in the future. Unlike The Pickup, the 2007 short story, "The Second Sense," offers a less idealistic view of assimilation and of the future of her female protagonist. In this story, Gordimer presents a couple who have emigrated to South Africa to start a life outside of Hungary like other immigrants who were "whites moving in on the blacks' country" (Gordimer, "The Second Sense" 269). To assimilate, Ferenc becomes "Fred," and his wife, Zsuzsana, uses an abbreviation of her name Szuzsi, because it "sounded like the familiar 'Susie,' common in English" (270). The narrative begins with the voice and perspective of Fred and his need "to make a living any way he can" (269). However, it isn't long before Zsuzana "who had no more schooling than in a small Hungarian town picked up the language easily," and "taught how to sew in accordance with the strict requirements of a female role imposed by her grandmother," is able to solicit clients for whom she made dresses (270). The couple also have a child together; "what better way to make claim to a new country" (270) to secure their place in their new environment.

As the story progresses, Fred struggles to find success in his new country. He wants to retain his former culture and impart that to his child, who resists his father's attempts to bond through language. Zsuzana on the other hand is able to penetrate female circles to further her social connections and to obtain more fulfilling work. She "had more 
women coming to be clothed by her" than she could accommodate (270). Through aligning herself with her female clients and learning their language, Zsuzana finds that she can use this connection to better her situation: "As the women for whose image she sewed were inclined to take someone outside their social circle into confidences about their lives she was herself beguiled in turn to confess" (271). Similar to the white South African women portrayed in The Pickent, the unnamed white women in this story are consumers with little depth and "are products of a profound sense of entitlement" (West 79). However, by ingratiating herself to these women and mimicking their behavior in order to be accepted in their social space, Zsuzsana is able to work in real estate and "the money she was bringing in eased some of the stringencies in their life" (Gordimer, "The Second Sense" 272). Zsuzsana's assimilation reflects a superficiality like that of her white clients and of the white South African women in The Pickup. By becoming one of them, she eradicates what is left of her former culture and ensures that her son, Peter, has every advantage she can provide. Even in intimacy with her husband, Zsuzsana, responds "softly in English" and no longer cooks the family meals since her new livelihood requires time and many late evenings. By the end of this short narrative, Zsuzsana "has decided upon a divorce" and "found home," while Ferenc "is in exile" (276).

Taken as a whole, the narratives in these selected works offer a range of characters who find ways to navigate a world that has rendered them inferior and dictated the spaces in which they should identify. The characters illustrate vast social differences based on race and gender as well as the consequences of occupying the space relegated to others through social rules and laws. Gordimer does not resolve the inequalities of her society, neither does she romanticize its past or present, but the trajectory of her writing has expanded her range of characters and settings to question cultural practices and in her later works to locate female spheres that offer unknown possibilities. The evolving nature of Gordimer's characters reflects the ever-changing roles that men and women are expected to play, in addition to her own development as a writer. Her contributions to literature are vast and offer much to our understanding of life in South Africa and beyond, of human nature and weaknesses, and of the notion of self and others. Gordimer forces her readers to "think of difficult things" (Clingman 9). However, Stephen Clingman's assertion that "Gordimer's writing is always in some way in dialogue with an absent future" (13) best summarizes her work. She was always looking ahead and beyond, but outward and inward as well.

Michelle GoIns-ReED

SUNY Broome Community College

\section{Works Cited}

BARKer, Derek A. "Crossing Lines: The Novels of Nadine Gordimer with a Particular Focus on Occasion for Loving and The Pickup." Literator 28.3 (Dec. 2007): 91-107.

Caraivan, Maria-Luiza. Nadine Gordimer and the Rhetoric of Otherness in Post-Apartheid South Africa. Newcastle upon Tyne: Cambridge Scholars Publishing, 2016.

Clingman, Stephen. "Nadine Gordimer: A Writing Life." A Writing Life: Celebrating Nadine Gordimer. Ed. Andries Walter Oliphant. London: Penguin, 1998. 3-18. 
Cloete, M.J. "A Study of Identity in Post-Apartheid South African English Literature: The Pickup by Nadine Gordimer.” Literator 26.1 (April 2005): 48-67.

DialA, Isidore. "Nadine Gordimer, J.M. Coetzee, and Andre Brink: Guilt, Expiation, and the Reconciliation Process in Post-Apartheid South Africa." Journal of Modern Literature 25.2 (Winter 2001-2002): 50-68.

Dimitriu, Ileana. "Postcolonialising Gordimer: The Ethics of 'Beyond' and Significant Peripheries in the Recent Fiction." English in Africa 33.2 (Oct. 2006): 159-80.

Driver, Dorothy. "Nadine Gordimer: The Politicisation of Women." English in Africa 10.2 (Oct. 1983): 29-54.

Gordimer, Nadine. A Soldier's Embrace. New York: Penguin/Viking, 1980.

—. The Pickup. Toronto: Penguin/Viking, 2001.

-. "The Second Sense." VQR 83.2 (Spring 2007) 269-76.

HEAD, Dominic. Nadine Gordimer. Cambridge: Cambridge UP, 1994.

Hunt, Emma. "Post-Apartheid Johannesburg and Global Mobility in Nadine Gordimer's The Pickup and Phaswane Mpe's Welcome to Our Hillbrow." Ariel: A Review of International English Literature 37.4 (October 2006): 103-21.

Knox, Alice. "No Place Like Utopia: Cross-Racial Couples in Nadine Gordimer's Later Novels." Ariel: A Review of International English Literature 27.1 (January 1996): 63-76.

LAzER, Karen R. "'Something Out There"': Something in There: Gender and Politics in Gordimer's Novella." English in Africa 19.1 (May 1992): 53-65.

Mohanty, Chandra Talpade. Feminism Without Borders: Decolonizing Theory, Practicing Solidarity. Durham: Duke UP, 2003.

Montle, Malesela, and Mphoto J. Mogoboya. "Re-Conceptualizing Identity in the Post-Apartheid South African Literature: Nadine Gordimer's The Pickup (2001)." Journal of Gender, Information and Development in Africa 7.1 (April 2018): 61-8.

Mount, Dana C. "Playing at Home: An Ecocritical Reading of Nadine Gordiner's The Pickup." Ariel: A Review of International English Literature 45.3 (2014): 101-22.

SpaIn, Andrea. "Event, Exceptionalism, and the Imperceptible: The Politics of Nadine Gordimer's The Pickup." Modern Fiction Studies 58.4 (Winter 2012): 747-72.

SpIvak, Gayatri. A Critique of Postcolonial Reason: Toward a History of the Vanishing Present. Cambridge: Harvard UP, 1999.

VISEL, Robin. “Othering the Self: Nadine Gordimer's Colonial Heroines." Ariel: A Review of International English Literature 19.4 (1988): 33-42.

West, Mary. "Portraits in Miniature: White English-Speaking South African Women in Selected Short Stories by Nadine Gordimer." English in Africa 37.1 (May 2010): 77-91. 